\title{
LEGAL OBSTACLES TO MINORITY PARTY SUCCESS
}

During the last ninety years, no national third party has succeeded in clisplacing one of the two traditional parties or even in retaining more than an insignificant fraction of popular support. ${ }^{1}$ With virtual unanimity, political scientists have attributed a major portion of the responsibility for this chronicle of failure to the exclusionary effect of the legal techniques ${ }^{2}$ by which the states avowedly seek to present the voter with a short, comprehensible list of alternatives on the general election ballot. ${ }^{3}$ It is the purpose of this comment to examine these statutory barriers in an effort to discover if they are unreasonably inhibitory and have, in fact, kept small parties off the ballot, or whether the explanation of the abortive careers of dissident groups lies somewhat deeper in the American political structure.

1. The Prohibition, Socialist, and Socialist Labor parties have most consistently appeared on the ballot in recent years. In the 1944 presidential clection, their national totals were: Prohibition, 74,758; Socialist, 80,518; Socialist Labor, 45,336. In this same election, the Republican and Democratic parties received a total of $47,608,783$ votes. 1948 World Almanac 279.

Nevertheless, dissident political groups continue to attempt this path to governmental control. See generally, Holcombe, The Political Parties of Today c.11 (1924); Odegard and Helms, Amertcan Politics c.4 (1938); Penniman, Sait's American Parties and Elections c.11 (4th ed. 1948). Ewing, Presidential Elections (1940) provides a breakdown of the minor party vote in presidential elections. A lighter treatment is found in the lectures of Hesseltine, The Rise and Fald of Tuind Parties (1948). See also Hicks, The Third Party Tradition in American Politics, 20 Mrss. VALIEY HIST. REv. 3 (1933).

2. "As if this catalogue of obstacles were not sufficiently disheartening new legal barriers have been brought forward . . . it is to be regretted that the tendency of recent years has been to raise such requirements to a figure which makes competition by third parties impossible." Brooks, Political Parties and Electoral Problems 122, 265 (3d ed. 1933). Demands for the tightening of laws relating to nominations tend "virtuatly to exclude political protestants from participation in primaries and conventions, while at the same time making it increasingly difficult for them to launch new party movements." ODEGARd AND HeLMS, op. cit. supra note 1, at 782. There is a "tendency which grows stronger year by year in state after state to monopolize the ballot for the Democratic and Republican parties by making the entry of new or minority party slates on the ballot alnost impossibly difficult." Thomas, Reflections of an Old Campaigner, 41 CommonWEAL 246 (1944). In Cort, Third Party?, 44 Commonweal 351 (1946), Harold Ickes is quoted to the effect that the election laws of many states make it "almost impossible" to put a third party on the ballot, and Dr. Frank Kingdon is said to have stated: "Don't go dreaming about a third party that can't be organized now. In 20 states we conldin't organize at all." (Emphasis added throughout.) Cf. AMERICAN Civil Liberties UNion, Minority Parties on the Ballot 6 (1943).

3. See Starr, The Legal Status of American Political Parties, 34 Am. Pou. Scr. Rev. 439, 455 (1940); Penniman, op. cit. supra note 1, at 263: "Perhaps it is not a mere persecution complex that suggests a conspiracy of Democrats and Republicans. [Sce note 2 supra]. Yet, in the main, the sense of grievance has no solid foundation. . . . Enthusiasts fail to see that, from the public standpoint, it may be desirable to keep the ballot from being encumbered and that very few voters think otherwise." $C f_{\text {., concerning the }}$ primary ballot, id. at 411-2. But see ANERICAN Civil LiberTies Union, op. cit. supra note 2, at 6-7; Note, Lintitations on Access to the General Election Ballot, 37 Cot. L. Rev. 86 (1937); The National Prohibitionist, Mar. 1, 1946, p. 1, cols. 1-4. 


\section{The Primari Election}

Established "political parties"-defined usually by a minimum percentage or number of the total votes cast in the last general election (ranging from $1 / 2$ of $1 \%$ to $25 \%$, and from 500 to 50,000$)^{4}$-are ordinarily required to nominate their tickets for the general election in party primaries. Groups receiving a minimal portion of the vote in a previous election, though not enough to qualify as regular "political parties," may nevertheless nominate by primary in one state, ${ }^{5}$ and three states allow any political group to participate in the primary by filing a petition. ${ }^{\circ}$ If in Florida $5 \%$, or in California $1 \%$, of the regis-

\section{TABLE I}

Nuniber of States Eampoytng Varjous Statutory Definitions of "Political Party."

No Defunition

Absolute numbers:

$50,000 \quad 1$

10,000

500

$\frac{1}{3}$

Percentage of:

Registered voters:

$$
\begin{array}{ll}
5 \% & 1 \\
1 \% & 1
\end{array}
$$

Vote at last presidential election: $25 \%$

1

Vote at last general election:

$\begin{array}{rr}20 \% & 3 \\ 15 \% & 1 \\ 10 \% & 6 \\ 5 \% & 4 \\ 3 \% & 3 \\ 2 \% & 4 \\ 1 \% & 2 \\ \text { of } 1 \% & 1 \\ & 24\end{array}$

\section{3}

3

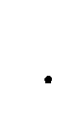

2

1

24
Percentage of last e'ote for:

Presidential electors: 1

Presidest: 1

Gocernor: 1

$5 \%$

$3 \%$

$1 \% 2$

$\overline{7}$

Congressional represcnlatiess: 3

$\begin{array}{ll}5 \% & 1 \\ 3 \% 0 & 1 \\ 2 \% & 1 \\ & \frac{1}{3}\end{array}$

Secretary of State: 1

$10 \%$

Any Statcaride candidale: $\quad 1$

Members of Gencral Assembly: 1 $10 \%$

While the above tabulation does not include Kansas, Nebrasha, and South Daloota, the figures total 48 because California, North Carolina, and Ollahoma have alternative definitions. Kansas deems any group having a state or national organization a party. Any' convention of 750 voters is recognized as a party in Nebrasla. In Soulh Daloto, any group submitting a petition signed by $10 \%$ of the last vote for Governor, prior to the primary, is a party.

In California, Illinois, Nevada, North Carolina, North Dal:ota, Ohio and Utah, a group may qualify as a regular party by submitting a petition previous to the primary. For the number or percentage of signatures required, and for data on individual states and statutory citations, see Charts pp. 1292-7 infra.

5. Kentucky and Oregon. For all statutory citations hereaiter, see Charts pp. 1292-7 infra.

6. Arizona, Oklahoma, and Wisconsin. And see note 4 supra. 
tered voters declare their affiliation with the new group well in advance, they may participate in the primary. ${ }^{7}$

\section{The General Election}

Holding their regulations to a minimum, eleven states condition the appearance of any political group's nominees on the general election ballot only on their being certified by a convention. ${ }^{8}$ Three others extend this privilege to groups which have participated in previous elections and have received varying degrees of support. ${ }^{9}$

Finally, in forty states a political faction may enter the general election by means of an independent nominating petition..$^{10}$ In a number of instances, one of the simpler techniques indicated previously is available, either in the alternative or exclusively; but far more frequently the direct petition is the only means of nomination that a protestant group may employ. Accordingly, the restrictions circumscribing utilization of this device are the target for most criticism of state ballot laws. Four principal problems are involved: (1) number of signatures required; (2) apportionment of signatures; (3) authentication of signatures; and (4) time for filing.

\section{Signatures Required ${ }^{11}$}

The number of signatures required ranges from $1 / 2$ of $1 \%$ of the vote for any successful candidate in the last general election to $5 \%$ of the registered

7. See discussion p. 1282 and note 28 infra.

8. Arkansas, Delaware, Idaho, Iowa, Michigan, Montana, Nebraska, New Mexico, Oregon, Tennessee, and Washington. In South Carolina, any group may print and dis* tribute its own ballots. New York, North Carolina, and Texas allow convention nomination of presidential electors. For the particular conditions surrounding each convention, see Charts pp. 1292-7 infra.

9. Indiana ( $1 / 2$ of $1 \%$ of last vote for Secretary of State); Massachusetts (1/10 of $1 \%$ in the last 3 biennial elections); and Vermont (1\% of last vote for Governor).

10. In Delazware, Idaho, Michigan, New Mexico and Washington, a new party nominates by convention. In South Carolina, any group may print and distribute its own ballots. It has been noted that this method destroys ballot secrecy. Amerrcan Civin LIBERTIES Union, op. cit. supra note 2, at 47. In North Carolina, a group qualifies as a party by submitting a petition of 10,000 signatures, and may then nominate its candidates tor presidential electors by convention. Since other candidates must be nominated by primary, they cannot be named until the year following that in which the party qualifics. See p. 1282 infra. In Florida, no provision is made for a new party by petition or convention. See p. 1282 infra. In Michigan, groups not receiving $2 \%$ of the last total vote for Secretary of State are permitted to nominate for certain offices by a petition bearing signatures equal in number to $1 \%$ of the last vote for Secretary of State. Micu. Srats. ANwo. c.57, $\$ 6.121$ (1936). But this provision appears repealed by implication. 1d., c.57, $\$ 6.349$ (Supp. 1947) (requires groups not qualifying as "political parties" to nominate by caucus or convention, and apparently covers the offices specified in $\$ 6.121$ ). See REp. AtT'y Gen. Mrch. 548 (1930-2); Jackson v. Corrections Commission, 313 Mich. 352, 21 N.W. 2d 159 (1946).

11. In all states, petition signers must be registered voters. In a number of states, a person is disqualified from signing an independent nominating petition if he has voted in 
voters, and, in the states using absolute numbers, from 15 to $25,000.12$ There

a party primary. In New York, for instance, a petition signer may register after signing an independent petition, Kerns v. Whiting, 187 Mfisc. 656, 65 N.Y.S. 2d 237 (Sup. Ct., 1946), but a person may not sign a petition if (1) he signed a primary designating petition; or (2) he voted in the primary. Sullivan v. Cohen, 180 Mise 780, 44 N.Y.S. $2 \mathrm{~d} 280$ (Sup. Ct., 1943). On the other hand, a Kentuchy court has held that it is immaterial that petition signers are registered as Republicans or Democrats and have voted in the party primary. Greene v. Slusher, $300 \mathrm{Ky} .715,190 \mathrm{S.W} .2 \mathrm{~d} 29$ (1945). In Rhode Island, those who have voted in a political party primary may not sign an independent petition for 26 months afterwards. R. I. GEN. LAws c. 316, $\$ 10$ (1938).

12.

\section{TABLE II}

Miethods Of Deterastning Petrmion Signatures Required By State.

(with approximate number required in states setting percentages higher than 1\%)

No independent petition method $\div$ : 8

Delaware

Florida

Idaho

Michigan

New Mexico

North Carolina

South Carolina

Washington

Percentage of:

Registered voters:

Georgia, 5\%(@55,000)

8 Absolute numbers:

24

Illinois

25,000

New York

Wisconsin

Oklahoma $\}$

12,000

Kansas

5,000

Minnesota

Afaryland

Louisiana

Iowa

Kentuchy

Ifaine

Nebraska

2,500

New Hampshire

2,000

New Jersey

1,500

Last vote for:

Governor:

$\left.\begin{array}{l}\text { Colorado } \\ \text { Rhode Island }\end{array}\right\}$

Massachusetts, 3\% (@ 50,000)

Oregon,3\% (@14,400)

Ohio, 1\% (@30,952)

Secretary of State:

Indiana, $1 / 2$ of $1 \%$

Successful candidate:

Miontana, 5\% (@11,000)

Alabama

North Dakota $\} \quad 300$

Utah

Virginia

250

1 Wyoming 100

1,000

Arkansas $\} \quad 50$

$\begin{array}{lll}1 & \text { Mississippi } \\ \text { Tennessee } & 15\end{array}$

Any elected candidate:

Pennsylvania, $1 / 2$ of $1 \%$

Last general election:

California,5\% (@135,000)

Nevada,5\% (@2500)

South Dakota, 2\% (@3400)

Mlissouri, 2\% (@31,000)

Arizona

Connecticut

Texas

West Virginia

Vermont

* See note 10 supra. 
appears to be no objective criteria to determine a reasonable signature requirement. The American Civil Liberties Union, in its model election law, has suggested a maximum of $1 / 10$ of $1 \%$ of the last total vote for governor. ${ }^{10}$ While so low a requirement may be desirable, a standard of $1 \%$ of the vote in the last general election would hardly deny the ballot to groups representing significant elements of the electorate.

Under the $1 \%$ criterion, only eight states may be regarded as imposing unduly severe requirements. ${ }^{14}$

\section{Apportionment}

Four states, ${ }^{15}$ apparently to discourage the rise of sectional parties, stipulate that each county be represented by a given number of signatures on the nominating petition, or in the alternative or as well, permit no county to furnish more than a set percentage of the signatures. Nowhere is the requirement prejudicial to a state-wide third party $;^{16}$ in each case, the maximum representation permitted a county on the nominating petition is well above the proportion of voters in state-wide elections resident in the county. Thus, in Massachusetts, for example, where no more than $1 / 3$ of the signatures may be obtained in any

13. Aarerican Civil Liberties Union, op. cit. supra note 2, at 12,15 .

14. California, Georgia, Massachusetts, Missonri, Montana, Nevada, Oregon and South Dakota. All the states setting the requirements in round numbers (sce note 12 supra) fall within the $1 \%$ classification. By the criterion suggested by the American Civil Liberties Union, only 17 states have reasonable provisions.

15. Illinois, Massachusetts, New York and Ohio.

16. Note must be taken, however, of the iniquities claimed by the Progressive Party to result from the apportionment requirement in Illinois: "When you consider that close to half of the entire population of the state is contained within one county (Cook), you can visualize the difficulty of securing the requisite number of signatures from the other 49. Most of these counties have an average population of 10,000 , only half of whom are registered voters in the first place. Of the 5,000 registered voters, roughly half voted in the primary [and are accordingly ineligible to sign] leaving a reservoir of 2,500 people from whom a minimum of 200 signatures must be gathered, and in order to be completely safe, approximately 300 signatures should be gathered." Communication to the Yale Law Journal from William H. Miller, State Director, Progressive Party, May 27, 1948. The requirement is perhaps prejudicial to any party seeking to speak solely for the residents of a small area within a state or for the urban or rural population exclusively. Cf. AseruCAN CIVIL LIBERTIES UNION, op. cit. supra note 2, at 4. 
one county, the 1944 presidential election figures show that the largest single county vote was $23 \%$ of the total..$^{17}$

\section{Authentication}

To minimize fraud, ${ }^{18}$ all states permitting the nominating petition require that signatures be authenticated. In most cases, this provision is satisfied by an affidavit by the circulator for the whole petition, or for each page. Six states,

\begin{tabular}{|c|c|c|c|c|c|}
\hline \multirow[b]{3}{*}{ State } & \multicolumn{2}{|c|}{ TABLE III } & \multirow{2}{*}{\multicolumn{3}{|c|}{$\begin{array}{l}\text { Higarest Snigle Cousity } \\
\text { Toraz VoTe In } 1944\end{array}$}} \\
\hline & \multirow[b]{2}{*}{$\begin{array}{l}\text { APPORTIONMENT } \\
\text { REQUIREAIENT }\end{array}$} & \multirow{2}{*}{$\begin{array}{l}\text { \%o of Sig- } \\
\text { NATURES } \\
\text { PER?STT- } \\
\text { TED FroMI } \\
\text { ONE } \\
\text { COUNTY }\end{array}$} & & & \\
\hline & & & County & Vote & $\begin{array}{l}\text { \%o of } \\
\text { Total }\end{array}$ \\
\hline Mrassachusetts & $\begin{array}{l}\text { No more than } r / 3 \\
\text { from any one county. }\end{array}$ & $331 / 3 \% 0$ & $\begin{array}{l}\text { Mfiddle- } \\
\text { sex }\end{array}$ & $\begin{array}{l}466,355 \text { of } \\
1,956,646\end{array}$ & $23 \%$ \\
\hline New York & $\begin{array}{l}12,000 \text {, with } 50 \text { from } \\
\text { each of } 61 \text { counties } \\
\text { (Hamilton and Ful- } \\
\text { ton counties are one } \\
\text { for this purpose). }\end{array}$ & $75 \%$ & Kings & $\begin{array}{l}865,946 \text { of } \\
5,466,245\end{array}$ & $16 \%$ \\
\hline Illinois & $\begin{array}{l}25,000 \text { with } 200 \text { from } \\
\text { each of } 50 \text { counties. }\end{array}$ & $60 \%$ & Cook: & $\begin{array}{l}2,200,026 \text { of } \\
4,089,248\end{array}$ & $54 \%$ \\
\hline Ohio & $\begin{array}{l}100 \text { from each of } 30 \\
\text { counties with no } \\
\text { more than } 25 \% \text { from } \\
\text { any one county. }\end{array}$ & $25 \%$ & Cuyahoga & $\begin{array}{l}548,483 \text { of } \\
3,153,056\end{array}$ & $17 \%$ \\
\hline $\begin{array}{l}\text { Michigan (Provision } \\
\text { apparently repealed } \\
\text { by implication. See } \\
\text { note } 10 \text { supra.) }\end{array}$ & $\begin{array}{l}100 \text { from each of } 20 \\
\text { counties and no more } \\
\text { than } 25 \% \text { from any } \\
\text { one county. }\end{array}$ & $25 \%$ & Wayne & $\begin{array}{l}\$ 70,940 \text { of } \\
2,191,322\end{array}$ & $33 \%$ \\
\hline
\end{tabular}

Source: 1948 World Alarartac 256, 261, 262, 267, 269.

18. "Fraud occurs most frequently where agents are employed and paid a few cents for each signature. As a rule, the public officers who check petitions perform this duty in a perfunctory way. At times, however, a careful examination has revealed the most outrageous impostures, the presence of fictitious names, and of names copied in the same handwritings from the register of voters or from the telephone directory." PEnsinsas, op. cit. supra note 2, at 411 . See also J. P. Harris, Regrstration of Voters in the United States (1929), and Election Adamnistration in the Uisited States (1934).

The Pittsburgh Press published the names of 4,800 Communist party petition signers in 1940. 1,800 claimed they did not know what they had signed. Thirty convictions followed for perjury, conspiracy, and obtaining signatures under false pretenses. A similar tactic has been employed in 1948 with respect to petitions for Henry Wallace. Again some signers have reneged: "they thought it was a petition for Palestine partition, or against 
however, insist that each signature be notarized. ${ }^{10}$ In five of these, the effect is to require individual authentication of from 300 to 3,900 signatures. And in Missouri, where approximately 31,000 signatures are necessary, ${ }^{20}$ each must be certified by a notary who personally knows the signer, or by two "credible" witnesses who can swear to his identity.

This latter kind of law deserves the most severe castigation; by no standard can it be adjudged a "reasonable" regulation of elections. Even where the number of signatures is as small as 300 , there appears no reason to impose such a requirement. An affidavit by each circulator covering the signatures he has obtained would seem to combine, in fairest balance, security for the state from fraud with absence of exclusionary restrictions on new groups.

\section{Filing Dates}

Independent nominating petitions must be filed in May or earlier of the election year in five states. ${ }^{21}$ Although nominations must certainly be closed at a reasonable time before elections to permit printing of ballots and concentration of voter attention on a limited number of alternatives, these desiderata might be adequately served by filing deadlines in July or August. Third parties would then nowhere be forced to develop and manifest their strength long before the voters' apathy has been dispelled by the imminence of elections.

\section{Miscellaneous Difficulties}

Four states must be separately mentioned. Florida makes no real provision for a new political party. Any group which at any time during the four years preceding the election year had $5 \%$ of the voters registered under its name, and nominates candidates for the primary, is a party. But no procedure for nomination by petition is provided.22 The North Carolina State Board of Elections has interpreted the law to exclude new parties from nominating candidates except for President and Vice-President until the primary election following the year in which the party qualifies. ${ }^{23}$ Unless a party in Ohio participates in the primary, ${ }^{24}$ it is apparently barred from nominating a slate of presi-

the city anti-smoke law, or against war; two confessed that 'I was drunk at the time'." Time Magazine, April 26, 1948, p. 66.

19. Colorado, Minnesota, Missouri, Texas, Utah and Vermont.

20. The technical requirement is $2 \%$ of the last general election vote. A total of 1,571,678 votes was cast in Missouri in 1944. 1948 Wordd Almanac 264.

21. Alabama, Maryland, New Jersey, Pentsylvania and West Virginia.

22. See Britten, Florida Prohibitionists Fight for Place on Ballot, The National Prohibitionist, March 1, 1945, p. 6, cols. 1, 2, 3.

23. This ruling was made March 20, 1948. See N. C. GEN. STAT. \$163-1 (1943). Communication from Attorney General of North Carolina to the Yale Law Journal, May $5,1948$.

24. Such participation would require submission of a petition signed by $1 \%$ of the voters at the last general election 90 days before the primary, or about February 4 , a date even earlier than the filing time considered unreasonable, fo 1282 stpra. 
dential electors in the same year that it is formed. ${ }^{25}$ In Louisiana, a petition must be signed by 1,500 voters not affiliated with any "political party." The task is a political impossibility ; $;^{26}$ the Democratic primary is invariably determinative of the election, and, in order to vote in the primary, a person must be enrolled with the party as well as registered to vote. Moreover, to change party affiliation, the voter must apply in writing to the local registrar.

\section{ReAsonable OR Restrictive?}

Of the eight states which do not employ the independent nominating petition, only Florida and North Carolina place unwarranted obstacles in the path of a new party's appearance on the ballot. ${ }^{27}$ Among the forty states permitting the petition, eighteen, with 235 electoral votes, unreasonably circumscribe its useby the standards here established-and afford no ready alternative.

Louisiana and Ohio are so classified in view of the special circumstances just set out above. Missouri must be categorized as dificult on two grounds: it sets an unreasonably high requirement for the number of petition signers, and in addition, obliges individual notarization of signatures. California,, 28 Georgia, Massachusetts, ${ }^{29}$ Nevada, and South Dakota all demand an unnecessarily large number of signatures on petitions. ${ }^{30}$ The requirement of individual notarization of signatures obliges stigmatization of Colorado, Minnesota, Utah, ${ }^{31}$ Texas, ${ }^{32}$ and Vermont. Finally, Alabama, Maryland, New Jersey,

25. This is the seemingly correct interpretation of the new Ohio statute: "On the presidential ballot shall be printed the names of the candidates for elcction to the offices of president and vice president of the United States, nominated as such by the national conventions of those parties at the next preceding primary election." Onı GE:. CoDs, \$ 4785-107 (Page, Supp. 1947). This interpretation was unsuccessiully challenged by the Prohibition Party in State $c x$ 'rcl. Mecartney v. Hummel, No. 31,410 (Sup. Ct. June 16, 1948) 150 Ohio St-(1948) ; The National Prohibitionist, Jan. 1, 1948, p. 1, cols. 1-4. The Wallace party has also attacked the provision. See PM, June 11, 1948, p. 6, cols. 5, 6.

26. AMrRican CTVIL LIBERTIEs Union, op. cit. supra note 2, at 24.

27. Delaz'are, Idaho, Michigan, New Mexico, and Washisgton all have simple convention requirements. South Carolina allows each party to print and distribute its own ballots.

28. In California, a group equal in number to $1 \%$ of the vote for any statewide candidate in the last general election may become a party by declaring itself to the losal registrar. But, since this action must be taken at least 75 days before the primary, it does not seem a sufficiently feasible alternative for a new party to permit removal of California from the difficult class.

29. A group which received $1 / 10$ of $1 \%$ of the total vote in the last 3 biennial cleetions in Mlassachusetts may nominate by convention. While this permits an established minority group to present its candidates with ease, the way is still barred to new dissident factions.

30. Montana and Oregon, as noted previously, require an inordinate number of signatures on nominating petitions, but a third party may nominate by convention.

31. Under Utah law, a group may become a party by filing a petition with 500 signatures, not individually notarized, previous to the primary. But, because this alternative requires intense party activity at so early a date, it will be of little value to a newlyformed group. Therefore it still appears necessary to consider the state as dificult.

32. A new group in Texas may, however, nominate presidential electors only by convention. 
Pennsylvania, and West Virginia ${ }^{33}$ fall into the difficult classification because they set extremely early filing dates.

\section{Effect of the Statutes}

There are, then, a number of unreasonable restrictions on the claims of dissident groups to appearance on the ballot. ${ }^{34}$ These impediments are, moreover, reinforced by a variety of social pressures, ranging from a discriminatory tone in judicial and administrative enforcement to the permitted use of violence against minor-party workers. ${ }^{35}$ Yet, these facts notwithstanding, a number of third parties have regularly appeared on the ballot in most states.

Thirty-three states have had places on their ballots for one or more minority party candidates in each of the last four presidential elections. ${ }^{30}$ Of the twenty states classified here as presenting unreasonable legal barriers, eleven have

33. The convention method alternately available in West Virginia affords no benefit on this count, for the convention must have been held by the time the petitions are duc.

34. In addition to the limitations forming the subject matter of this discussion, nine states, Arkansas, California, Delaware, Kansas, Ohio, Oklahoma, Tennessce, Wisconsin and $W$ yoming prohibit the appearance on the ballot of groups which: (1) advocate the overthrow by force of the government of the state or of the United States; (2) carry on a program of sabotage, force, violence or treason; or (3) are affiliated with a named organization or with any foreign government or organization or with any group which advocates the overthrow by force of the government of the state or of the United States. Five of these states also require a new party to file an affidavit discussing subversive aims. Texas specifically bars candidates of the Communist, Nazi and Fascist parties from running for office. All state laws predicating ballot appearance on political orthodoxy may, at least in part, be constitutionally offensive. See Communist Party v. Peek, 20 Cal. 2d 536, 127 P.2d 889 (1942); Feinglass v. Reinecke, 48 F.Supp. 438 (D.C. IIl. 1943); Groner, State Control of Subversive Activities in the United States, 9 FED. BAR J. 61 (1947); Comment, Special Legislation Discriminating Against Specified Individuals and Groups, 51 Yale L. J. 1358 (1942) ; Note, Statutes Banning the Communist Party, 54 HARv. L. Rev. 155 (1940). But cf. Field v. Hall, 201 Ark. 77, 143 S.W.2d 567 (1940).

On the doctrine of guilt by association, an integral part of all the above statutes, sce Bridges v. Wixon, 326 U.S. 135 (1944); Schneiderman v. United States, 320 U.S. 1 (1943); O'Brian, Loyalty Tests and Guilt by Association, 41 HARv. L. REv. 592 (1948); Note, Constitutionality of the Taft-Hartley Non-Commnnist Affidarit Pravision, 48 Cot. L. REv. 253 (1948); Comment, In re Harry Bridges, 52 YALE L. J. 108 (1942).

A Penisylvania statute, much narrower than those of the above states, is in all probability so worded as to escape constitutional attack.

These attempts to limit the outer fringes of protest opinion by statutory interdiction do not appear epidemic. The ten state laws currently in force were passed in 1941 or before. Many other states have since considered such legislation and refused to pass it, and a few states have repealed statutes enacted earlier. Ward, The Commmnist Party and the Ballot, 1 BiLl of Rights Rev. 286 (1941).

35. American Civil Liberties Union, op. cit. supra note 2, at 8. Cf. Graham v. Moore, 56 Ariz. 106, 105 P. 2d 962 (1940). See also the technique of publishing the names of petition signers, note 20 supra. Such publication is required by Maryland law. Md. Code ANwo. Art. 33, $\$ 44$ (Flack, Supp. 1947). For a minority party's version of such difficulties, see Proceedings, Nattonal Convention of Socinlist Lanor Party 221-8 (1940).

36. All except Florida, Louisiana, Maryland, Nebraska, Nevada, New Hampshirc, 
regularly permitted one or more third party candidates to seek office. ${ }^{37}$ Today,

New Mexico, North Carolina, Ohio, Oklahoma, South Carolina, South Dalsolo, Vermont, West Virginia, and Wyoming. 1948 Worrd Alaranac 251 ff.

In 1944, the Socialist and Prohibition Parties each presented candidates in 27 states.

William Lemke's new Union Party had a slate in 35 states in 1936. Ibid.

37.

TABLE IV

Minortty Parties On The Ballot In "Difficult" States

1944

(with total zote

State

received)

1940

1936

Alabama

S 190

Proh 1,095

Colorado

S 1,977

California

S 3,923 SL 327

Proh 14,770

Florida

0

Georgia

Proh 36

ID 3,373

Louisiana

Maryland

ID 69

Massachusetts

0

Proh 973

SL 2,780

Minnesota

$S 5,073$

SL 3,176

Missouri

$S 1,750$

Proh 1,175

SL 221

Nevada

New Jersey

53,358

Proh 4,255

SL 6,939

North Carolina

Ohio

0

C, S, Proh

C, S, Proh

C, S, Proh

C, S

C, Proh, Prog

C, S, Proh

0

0

Proh, ID

0

ID

C, S, LP

C, Proh, SL, S

S, Proh

C, S C, S

0

S

, S, Proh

S, Proh, SL

C, S, Proh

Pennsylvania

S 11,721

Proh 5,720

SL 1,789

South Dakota

0

TR 135,439

Proh 1,017

0

0

Texas

S 594

AF 250

Utah

S 340

Vermont

West Virginia

0

C, $\mathrm{S}$

0

C, S, Proh, SL

C, S, Proh

In 19363 states had no third party candidates. The number climbed to 11 in 1940, and to 10 in 1944. In the last year, however, the Communists ran no national tickets.

Symbols:

0-no third parties
C-Communist
S-Socialist
Proh-Prohibition

SL-Socialist Labor

Prog-Progressive

ID-Independent Democrats

LP-Labor Party
AF-Amerien First

IG-Independent Government

U-Union

TR-Texas Regulars

Source: 1948 WorLo Alarasiac 251 ff. 
the Wallace party is confident that its ticket will be presented in more than forty states, and thus far has been excluded in only two. ${ }^{38}$

\section{DeDUCtions From the Data}

The foregoing statistical analysis suggests that some material revision of the current attitude that state ballot legislation throttles third parties is in order. The primary conclusion that may be drawn from the analysis is that a protestant group must have a minimal amount of popular support to place its ticket on the general election ballot. But to gain this support is hardly an additional obstacle for a third party. Its decision to act independently is usually prompted by a desire to replace one of the major party organizations. ${ }^{30}$ If it is to accomplish this aim, support on a scale far larger than present ballot requirements is necessary.

The task of a third party seeking major-party status is formidable in a society which generally employs the plurality election system. ${ }^{40}$ To attract the necessary support under these conditions, it must compete with two major parties with professional, nation-wide organizations. The record amassed by the established parties in consistently capturing the machinery of government ${ }^{41}$ confers a material advantage in the eyes of the voter interested in putting a program into effect, as it also provides an opportunity to reap the rewards of patronage disbursement. ${ }^{42}$ Less rational, but nonetheless of enormous signifi-

38. Florida and Oklahoma. See discussion of Florida p. 1282 supra. N. Y. Times, June 6,1948, p. 38, col. 1. In Oklahoma, the petitions submitted by Wallace backers were challenged under that state's ballot loyalty law. Cooper v. Cartwright, No. 33,588 (Sup. Ct.); Davis v. Foote, No. 117,775 (D. C. Okla. County). On June 12, the State Supreme Court ruled that the Wallace Progressives did not constitute a political party under Ok:lahoma laws. N. Y. Times, June 13, 1948, p. 23, col. 7. On the doubtful status of minority parties under the new Ohio law, see note 25 supra.

39. Norman Thomas, perennial socialist presidential candidatc, has aptly voiced this ever-springing, if perhaps wistful, hope: "Socialists and others who have tried to build 'third parties' have always acted in the hope of becoming a first or second party, as did the Republicans between 1856 and 1860." Reflections of an Old Campaigner, 41 CounosWEAL 246, 247 (1944).

40. For an excellent discussion of the effects of the electoral system on minor parties, see Schattschneider, Party Government 74-80 (1942). It should also be noted that there are other aspects of our governmental system that make successful third party action more difficult. One author lists among "political" difficulties: the decentralized nature of our government with its division of powers between national and state governments; the directly elected executive, an office fully as important to capture as the legislature; and the power of the Supreme Court to set aside legislation. Douglas, The Coming of a NEw PARTY 129-38 (1932). He includes as well under this category the legal requirements of ballot legislation. For further discussion, see Brooks, op. cit. supra note 2, at c.7; Holcombe, The Political Parties of Today, c.11 (1924); Odegand and Helus, op. cit. supra note 1 , at c.23.

41. "There are only two candidates representing the two major partics with a chance of winning. The voters want to try to help pick the winner." Thomas, supra note 39, at 246.

42. Patronage is the means both of gaining actual support and of maintaining and 
cance in explaining the "traditional" support given the two parties, are the infiuence of family ${ }^{33}$ and the symbol value of party principles in given communities. ${ }^{44}$

To overcome these handicaps, a third party must break new ground. There is no fund of traditional straight party-line strength to draw upon. Instead, every vote is a conscious vote for the new party. To make the voter willing to cast it obviously involves the elaboration of a program designed to attract votes. But by far the most important task is that of organization. This task is not merely one of recruiting personnel to advocate the program; required is the development of a feeling in the individual voter of participation in the party's affairs, and a will to seek the solution to his problems through the new organization.

Demonstrative of the validity of this analysis are the presidential campaigns of Theodore Roosevelt in 1912 and Robert La Follette in 1924. They were the most successful third party efforts since the Civil War, Roosevelt actually polling a larger popular and electoral vote than Taft. Yet, for different reasons, both movements disintegrated before the next presidential elections.

The $\mathrm{La}$ Follette candidacy was an attempt to make an appeal solely to pro-

building up a party organization that can continue to appeal effectively to the electorate. A good example of its possibilities was provided in the New Deal era. "The new serviees performed by the national government brought about a vast extension of the civil service, largely outside the merit system. By June 30, 1937, 280,000 new jobs had been created; and patronage has always been the chief resource of politicians in building a machine" Penniacan, op. cit. sutpra note 1 , at 235.

43. Merriam and Gosnell observed some time ago that the voter's preference for the Republican or Democratic party is not based on principles and program. They have estimated that about $75 \%$ of the voters have a "hereditary" allegiance to one or other of the two parties. The American Party Systear 28 (2d ed. 1929).

44. "To the south of the Mason-Dixon line, ... the Democratic party has been thought of in a sentimental revery of wisteria and moonlight as the body which enabled the South before the Civil War to dominate Capitol Hill and during the Reconstruction period to overthrow negro and carpetbag government and thus make Southern Caueasian civilization safe at last. ... Nor are the native Anglo-Saxons alone in sharing these passionate attachments. The negroes in the northern and border states feel indebted to the party which gave them freedom and cast their votes with almost complete regularity for it. . . The Germans of the Mississippi Valley threw their lot in with the Republicans at the time of the Civil War and the memory of Sigel's Division still esercises its sway over large groups of sturdy burghers. In the Northwest, the Seandinavians who poured in after the Civil War to settle Mfinnesota and the Dakotas came to feel that it was Jim Hill and the Republican Party which gave them their homesteads and whose everlasting arms buoyed them up. . . ." DougLAs, op. cit. stipra note 40, at 122 . The fact that these traditional attachments are, of course, subject to change is borne out by the shift of the Negro vote to the Democratic party during the New Deal ers. Otzsaro A:D HeLars, op. cit. supra note 1, at 793, note that the very vagueness of principles is an asset to the two parties: "Thus in one state they may be radically pro-labor and pro-agrarian, or both, while in another they may be equally pro-business, in one section wet and in another dry, thus cutting the ground from under any new party appealing specifically to any one of these interests." 
gram and personality. Pending the results of the election, organization on the local level was deliberately postponed. ${ }^{45}$ La Follette's vote of about 4,700,000, representing some $16 \%$ of the entire popular vote and an electoral vote of 13,46 hardly met expectations. The movement soon collapsed as a result of the loss of its leader and the absence of an organization to sustain it. ${ }^{47}$ On the other hand, the Bull Moosers of 1912 had not only a popular leader and an attractive program, but also an impressive organization. ${ }^{48}$ Their popular vote of $27 \%$ and electoral vote of 88 might be said to approximate the maximum that could be expected in a first trial of strength with two functioning major parties. The great question centered around the ability to maintain this new organization and to secure an even greater popular support for the next presidential election. But the preliminary answer given in the Congressional elections of $1914^{49}$ clearly pointed out the movement's shortcomings. Its support in 1912

45. Announcing his candidacy in 1924, Senator La Follette declared: "Permanent political parties have been born in this country after, and not before national political campaigns, and they have come from the people, not from the proclamations of individual leaders. ... If the hour is at hand for the birth of a new political party, the American people next November will register their will and their united purpose by a vote of such magnitude that a new political party will be inevitable." Quoted in DOAN, THE LA FoliETtes AND THE Wisconsin IDEA 125 (1947).

46. La Follette was able to carry only his home state, Wisconsin.

47. La Follette died seven months after the election. With respect to the organizational problem, Hesseltine observes that: "The lesson that a party needed local candidates, wardheelers, and door-bell ringers was made more obvious by the Congressional returns. The 69th Congress, elected in 1924, had a majority of stalwart Coolidge Republicans, and the Party's insurgents no longer held a balance of power." HESSELTINE, op. cit. supra note 1 , at 33 .

La Follette was successful in the one state where he had built up an effective personal machine capable of assuring him continued support whether working through the Republican primaries or an independent political movement.

48. The Progressive Party in 1912 was, of course, organized by the insurgent wing of the Republican party. Intra-party fighting with the conservatives and regulars had prepared the group for the practical tasks of political organization. Moreover, they held important positions in state and national government. See The Autonrography of WinLIAM ALLEN White 60-4 (1946). In no fewer than 16 states Roosevelt men were on the electoral tickets of the Republican party. In a last-minute effort two or three weeks before the election, Republicans finally "purged" these tickets in every state except California. There the Progressives did not lose control of the machine, and did not permit any ticket to be voted by loyal Republican supporters. 2 Stanwood, A History of THE PRESIDENCY 300-1 (2d ed. 1916).

So strong was the Progressive organization that even as late as 1915 the party's chances of survival appeared favorable: "That this is likely is shown not only by the fact that the new party controls several of the largest states, but also by the fact that in states where it is comparatively weak, as in New York, thorough party organization has been effected. Lecture bureaus, educational bureaus, and legislative drafting bureaus have been formed for the purpose of aiding in the solution of vital social and economic problems of modern life so far as they are affected by government." DEWITT, TuE ProGRESSIVE MOVENENT 88 (1915).

49. "The Progressives lost 8 members of the House, falling from 15 to 7 while their popular vote in the country did not reach one-half . . . what it was in 1912. The decisive de- 
had been a protest vote. Allegiance had not been transferred from the two major parties. As a result, the Progressive movement became "a group of leaders without followers." date in 1916 was the signal for a collapse even among the leadership and it was a reunited Republican party that fought the 1916 campaign.

This experience puts the problem of the legal requirements of ballot legislation in a more realistic light. To compete successfully with the major parties a third party must organize and develop through time; it can not stake all on one spectacular bid but must anticipate the exigencies of permanence. If this attitude is taken, ballot legislation imposes no new demands. The collection of a given number of signatures within a specified time tests the strength of the new organization and can well become a possible means of gaining the necessary contact with the individual voter. ${ }^{\text {.1 }}$ The requirement that such signatures be divided over a given number of counties is but a call to develop the extensive local organization without which a party cannot hope to win an election. The suspicion becomes all too strong therefore that complaints about legal requirements are either attempted shields for inadequacy or evidence of unwillingness to think realistically.

Indeed, a consideration of the record of third party endeavor might suggest that the greatest hopes for success lie in pursuing tactics other than an attempted replacement of one of the two major parties. Direct primary legislation in all but one state ${ }^{52}$ offers the tactical possibility of "boring from within." Instead of facing the organizational difficulties involved in capturing political power through independent action, a protestant group has the far simpler alternative of capturing a major party organization by persuading the party members to nominate dissident candidates as their standard-bearers.

The successful use of this tactic has not brought about the loss of organizational strength. In the interests of winning the general election for the party, the personnel of the organization has generally supported the successful candidate. ${ }^{53}$ Nor are the other advantages of minor magnitude. First, the protes-

cline of the Progressive vote was one of the most significant features of the clection which indicated that the Republican party would be looked to as the leading party of the opposition and that the country preferred to maintain the traditional two-party system." See Woodburn, Politics and Parties, Axr. Y. B. 47, 53 (1914).

50. See The Autobiography of WinliaAr AuleN White 517 (1946).

51. The petition method is obviously of value for purely publicity purposes, for the regular appearance of petition distributors helps make the party a familiar institution, while the collection of more signatures than the total required may well impress voters with the support gained. A good example is provided by the Wallace movement in California, where legal status was recently attained with the collection of 461,280 signatures, three and one-half times more than necessary.

Still another reason for the collection of superfluous signatures is the fear of invalidation of petitions.

52. Connecticut still has the convention system. For details of the various systems possible, see Penniman, op. cit. supra note 1, at 303-4.

53. See remarks of Senator Borah: "Any man who can carry a Republican primary is a Republican. He might believe in free trade, in unconditional membership in the 
tant group is given a preliminary opportunity to compete for support among a smaller number of the electorate, for only the voters of the party within which the struggle takes place are involved. Secondly, the voter is not asked to break his traditional ties with either major party. Finally, the successful candidate benefits in the general election not only from the support of his own faction but also from the votes of those who traditionally vote the straight party ticket.

These observations do not present a mere theoretical possibility. The most famous instance of an independent group capturing a major party organization was the success of the Non-Partisan League of North Dakota. Selecting candidates in its own conventions, the League placed them in the primaries of the Republican party. ${ }^{54}$ In 1916 , it won the primary, gained control of the party organization, and won the general election. In 1920 and 1922, its candidates won the state's seats in the United States Senate. ${ }^{55}$ Spreading its influence to some dozen states, ${ }^{56}$ the League usually employed the same tactics. Only in Minnesota and South Dakota, where the League failed to capture a major

League of Nations, in states' rights, and in every policy that the Democratic party ever advocated, yet if he carried his Republican primary, he would be a Republican. He might go to the other extreme and believe in the communistic state, in the dictatorship of the proletariat, in the abolition of private property, and in the extermination of the bourgeoisic, yet if he carried his Republican primary, he would still be a Republican." Berdahl, Party Menbership in the United States, I, 36 AM. PoL. Scr. REv. 16-7 (1942). James Farley observed: ". . . the vendetta must end when the nominations have been made. Party loyalty is requisite for party success. Discipline is as necessary in the ranks of a political organization as in the files of an army. As your national chairman, I have announced with all sincerity and without reservation that the national committee is behind every Democratic nominee. That has to be the guiding tenet of every honest Democrat if we are to continue in power in state and nation." Id. at 18.

In some states, e.g., Ohio, no one who has been defeated in the primary may become a candidate in the general election. In the Solid South, party rules frequently produce the same result. See Penniman, op. cit. supra note 1, at $410-1,431$.

Note, however, that on occasion the party organization has refused to go along with the successful primary candidate. For example, Montana Democrats in 1920 refused to support the successful candidate of the Non-Partisan League. PENnMan, op. cit, supra note 1 , at 149 .

54. The placing of candidates on primary ballots also necessitates compliance with various legal requirements. In this respect, the League's experience is interesting. Its well-knit organization extending down to the individual farmer in each locality had no difficulty in getting signatures and regularly amassed far more than the minimum requircd.

The League met virtually every obstacle that a protestant group seeking power might expect to encounter. Since its tactics represented a novel use of the party primary and its program was a modified form of socialism, every effort was made to discredit the organization. Newspapers launched a campaign of vilification. A rival organization was set up. Old party leaders attempted to bar League men from sitting on party committces. Yet in the face of these pressures, the League maintained the loyalty of its members and was able to achieve its limited aims. See Gaston, The Non-Partisan League, cc. 9, 10 (1920).

55. Senators Ladd and Frazier.

56. The League successively entered Minnesota, South Dakota, Montana, Idaho, Washington, Colorado, Nebraska, Iowa, Oklahoma, Kansas, Texas and Wisconsin. 
party primary, did it resort to third party action. The magnitude of the League's success in the early twenties may be measured by the fact that men of the radical farmer delegation whom it had helped nominate and elect held the balance of power in the Senate. ${ }^{.7}$

In comparison with the difficulties confronting independent political action, this experience of the Non-Partisan League points out an avenue of the greatest potentiality for an independent group. ${ }^{.8}$ It should be noted, however, that the practical problem of organizing support, although simpler, is not avoided. The primary election must still be won, entailing a struggle possibly requiring years for eventual success. A group may thus face delay in presenting its program to the entire voting public. But if its aim is to capture power, this immediate disadvantage is offset by the possibility of working under far more favorable conditions to reach its goal.

If, on the other hand, a group, out to call attention to certain needed reforms, makes this educational function its primary aim, the tactical advantages the primary system offers may well become secondary considerations. By the same token, the maximal hope of third party action under these circumstances can only be the adoption of its program by one of the major parties. This is not to belittle the educational function third parties can play. ${ }^{* 0}$ Indeed, it becomes the only possible hope for groups, such as the Prohibition Party, which have consistently placed candidates in the presidential elections but have failed to compete seriously with the major parties. Again, however, the practical problem of finding support is far from totally avoided. If the major parties are to become interested in a given program, a third party must be able to attract a considerable following. Once more the gaining of convincing support over and beyond the requirements of ballot legislation will be the obstacle facing third party action.:

57. Senators Ladd and Frazier of North Dakota, LaFollette of Wisconsin, Brookhart of Iowa, Howell of Nebraska, and Shipstead of Minnesota, the latter elected by the successful action of the newly-formed Farmer-Labor Party. See Rowell, Why the Mfiddle West Went Radical, 46 Worr.D's Work 157 (1923).

58. Indeed, Robert LaFollette, despite his open opposition to many of the policies of the Republican party, was also able to work through the Republican primary system in order to return repeatedly to the Senate.

In one-party regions such as the South, the primary offers the only real opportunity for a decision among conflicting groups and principles.

Today, the control of the Democratic-Farmer Labor party of Arinnesota is openly disputed by the Truman and Wallace factions. In February of this year, former Governor Benson openly predicted Wallace would win the party's primary and would thereby force President Truman to seek nomination via the petition procedure usually reserved for minor party candidates. N. Y. Times, Feb. 12, 1948, p. 8, col. 5, June 15, 1948, p. 31, cols. 6, 7.

59. It is difficult, however, to evaluate the influence of third party movements in this field. Perhaps, the most successful instance was provided by the Populist Party which gained the largest third party vote prior to the 1900 's. But many other claims can casily be countered by more plausible explanations. For example, the Anti-Saloon Ieague, not the Prohibition Party, was seemingiy most influential in arousing public support for the 18th Amendment. See Pensmaran, op. cit. sipra note 1, at 262.

* This Comment was prepared jointly by a member of the Journal Board together with Karl Cerny, Graduate Student, Department of Political Science, Yale University. 


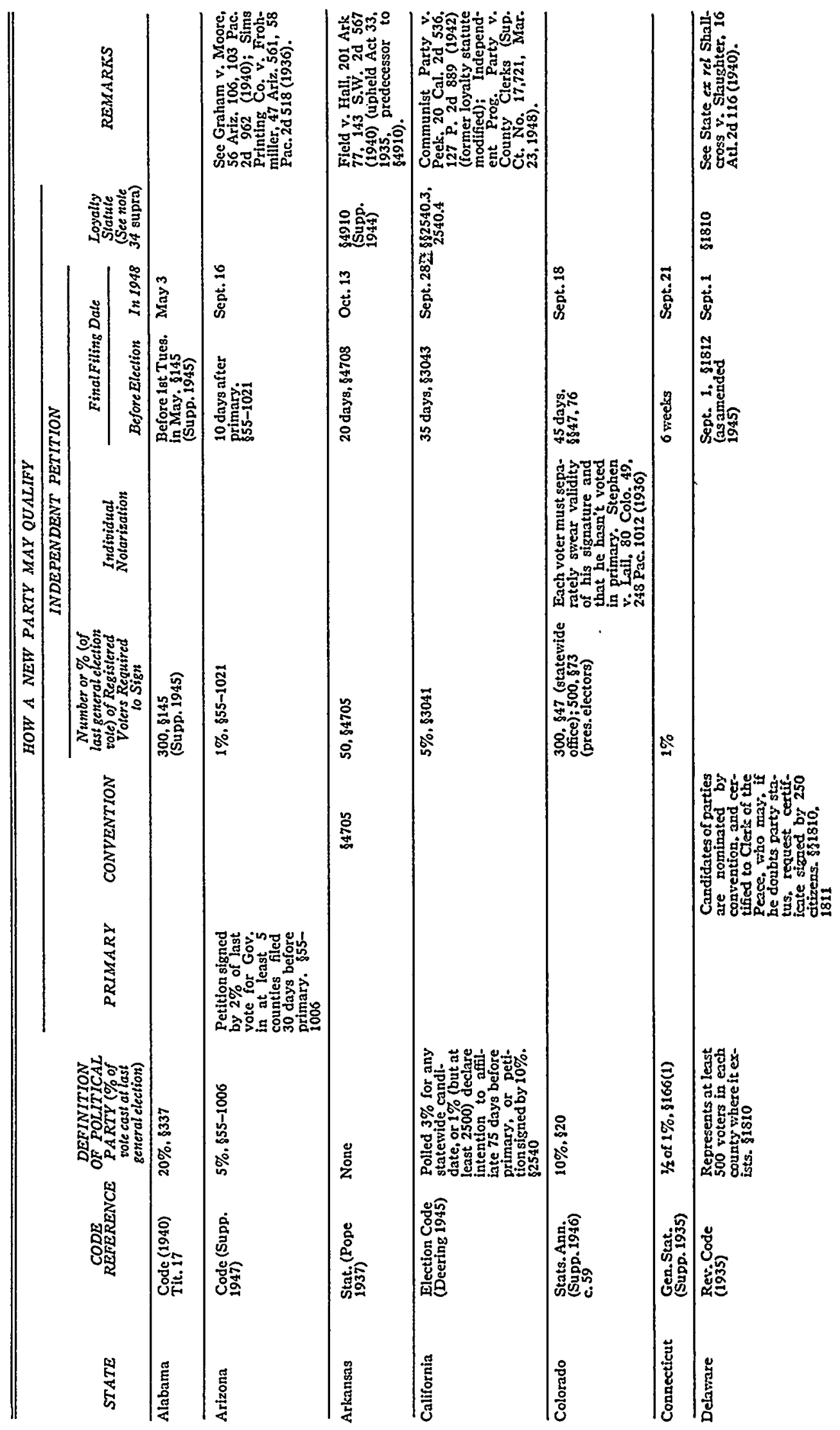




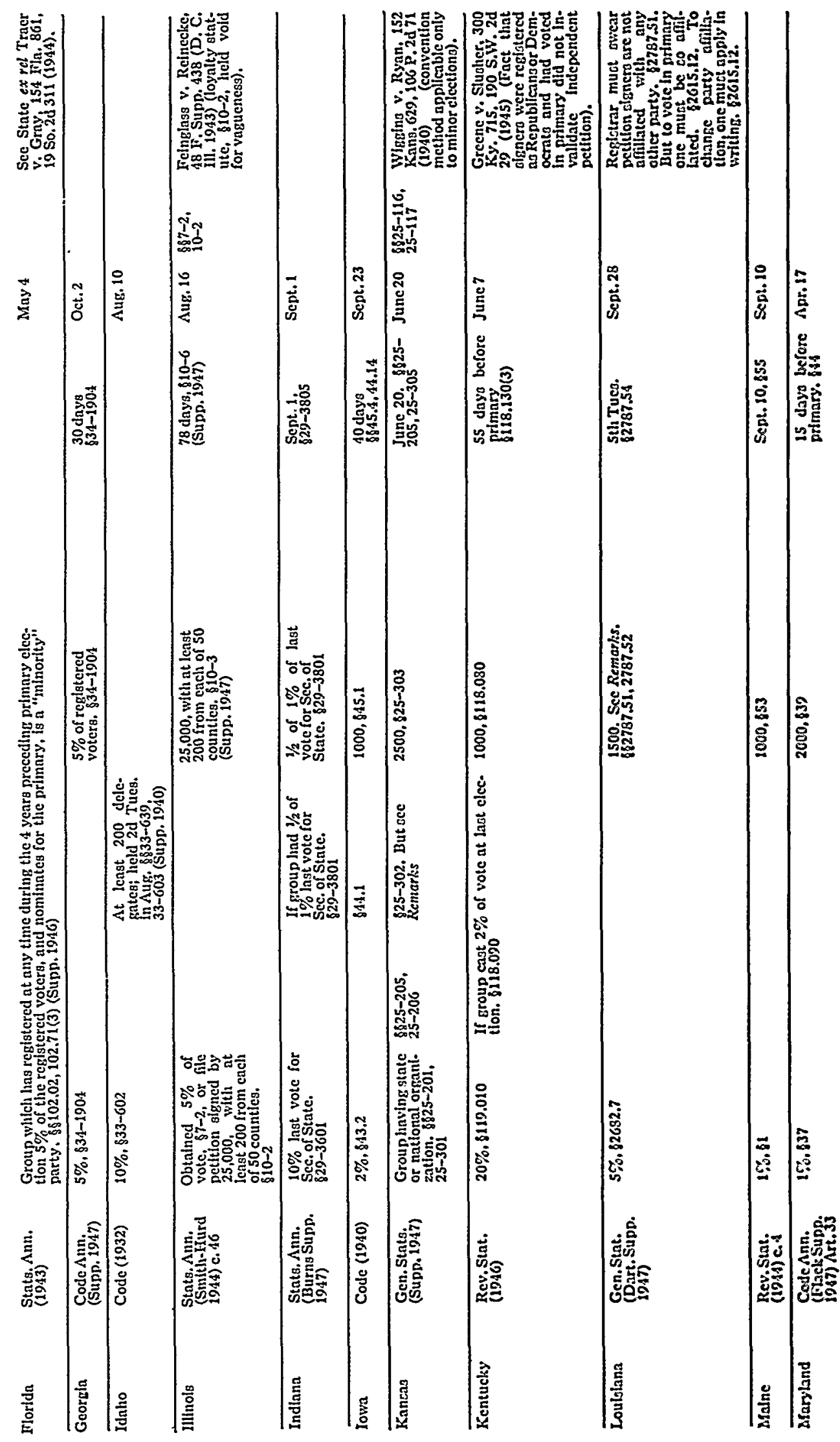




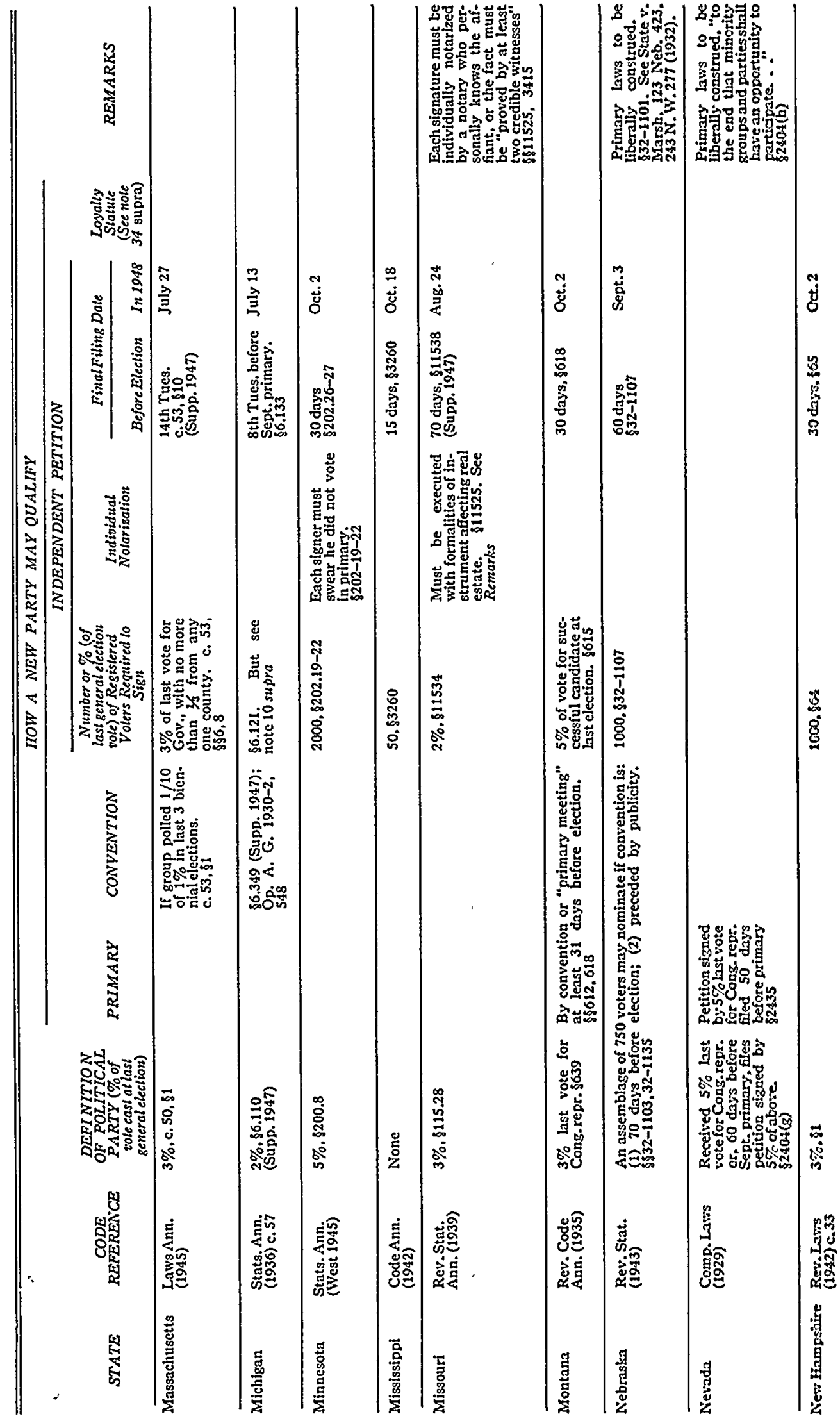




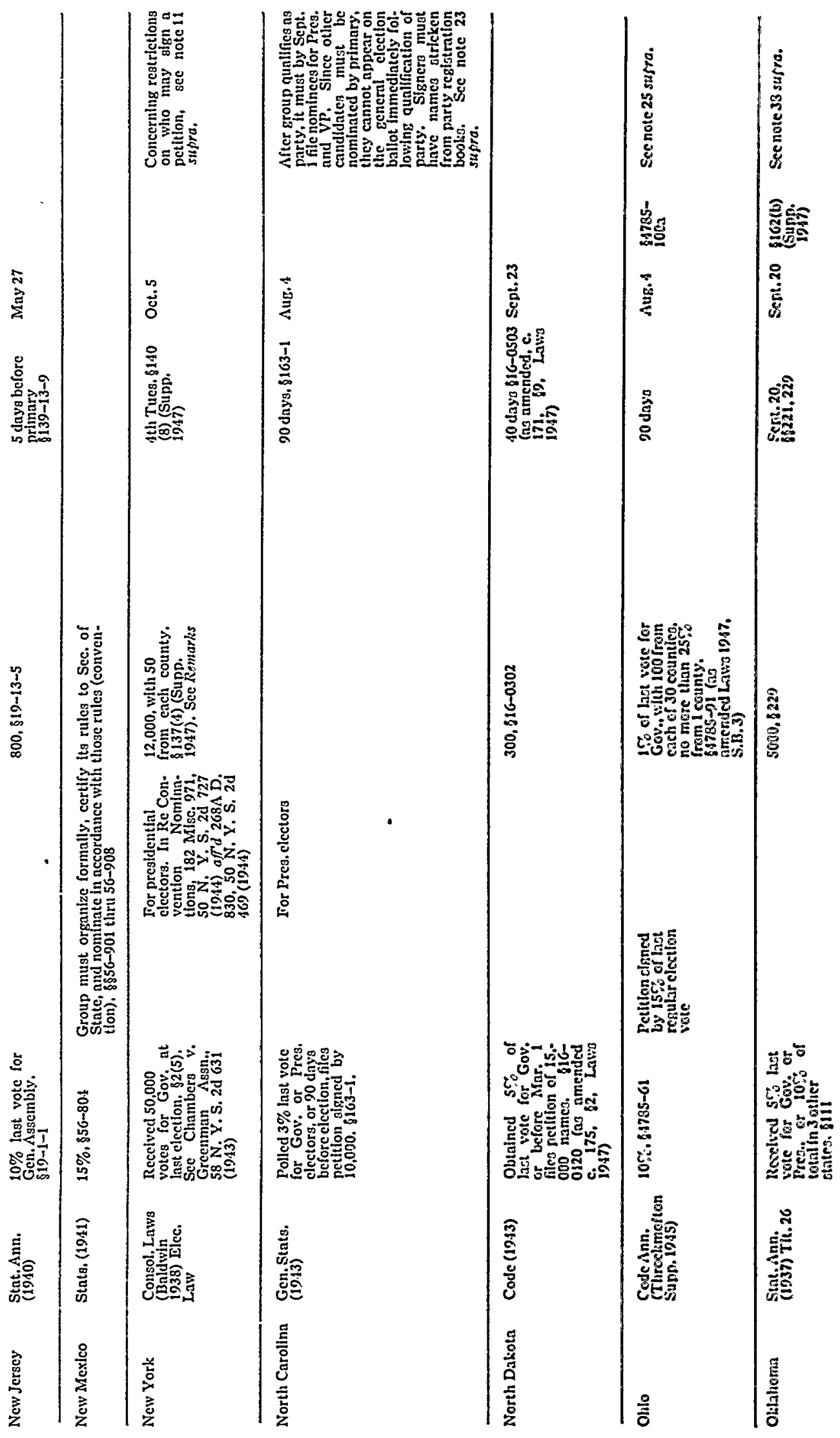




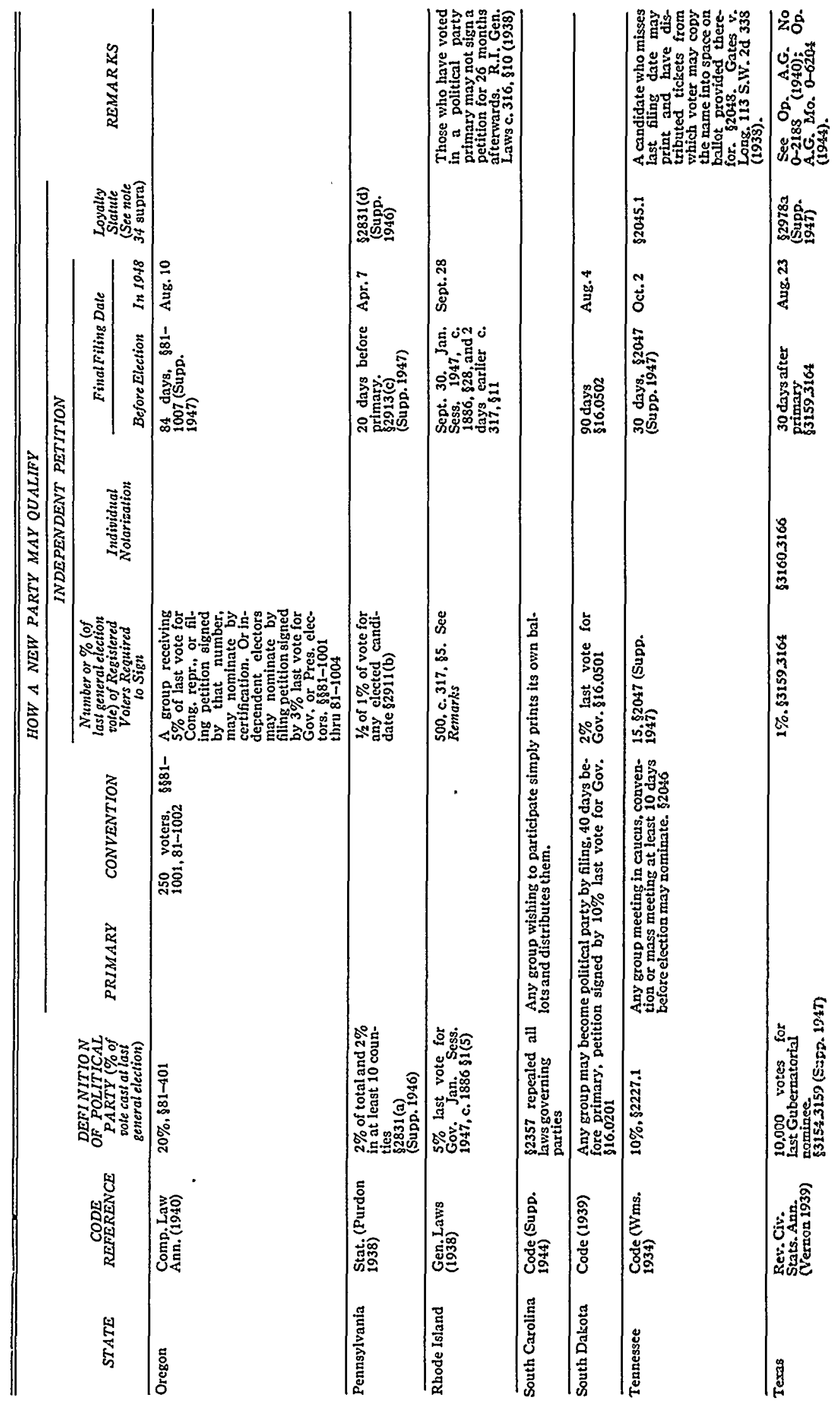




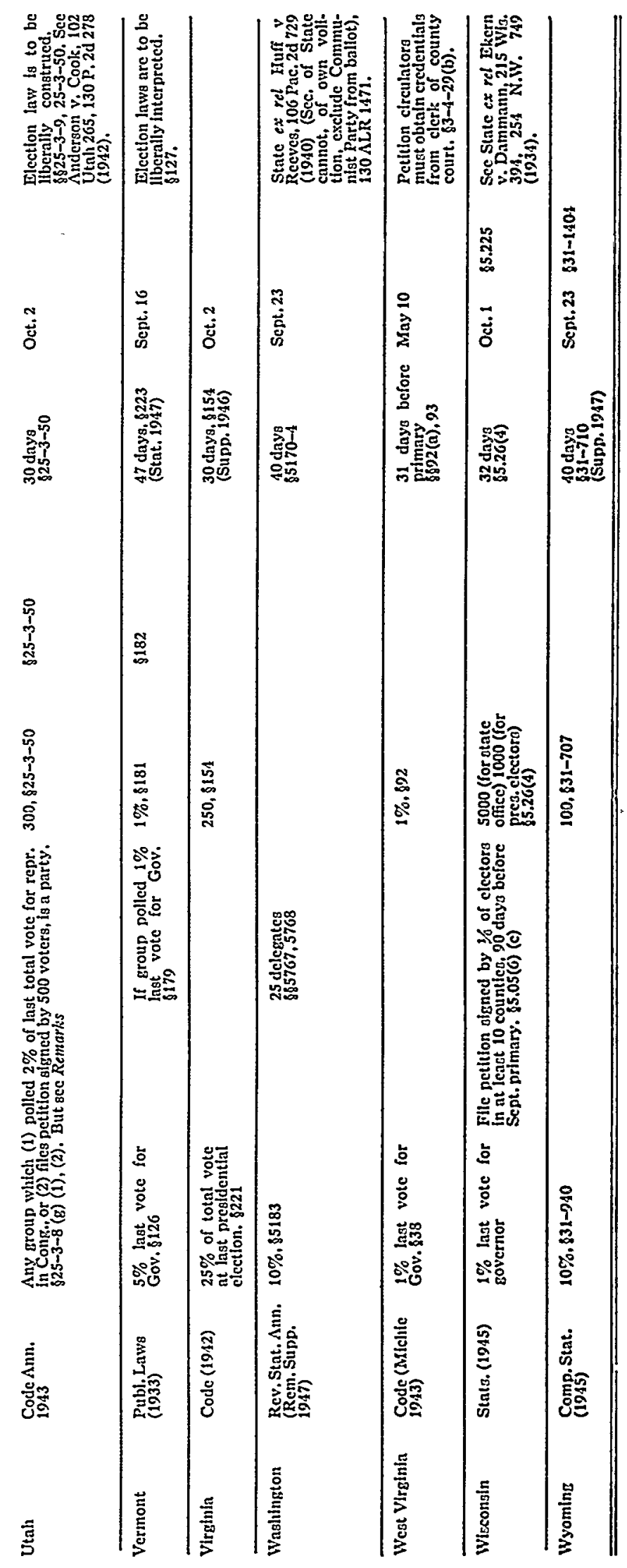

